\title{
Prophylaxis of osteonecrosis in the case of patients treated with bisphosphonates: A review paper
}

\section{Zapobieganie martwicy kości u pacjentów leczonych bisfosfonianami - przegląd piśmiennictwa}

\author{
Paweł Nieckula ${ }^{1, A-F}$, Anna Stempniewicz ${ }^{2, A-D}$, Monika Tubaja ${ }^{2, A-D}$ \\ ${ }^{1}$ Department of Dental Surgery, Faculty of Medicine and Dentistry, Medical University of Warsaw, Poland \\ ${ }^{2}$ Medical University of Warsaw, Poland \\ A - research concept and design; $B$ - collection and/or assembly of data; $C$ - data analysis and interpretation; \\ $D$ - writing the article; $E$ - critical revision of the article; $F$ - final approval of the article
}

\author{
Address for correspondence \\ Anna Stempniewicz \\ E-mail: stempniewicz.ania@gmail.com \\ Funding sources \\ None declared

\section{Conflict of interest} \\ None declared

\section{Acknowledgements} \\ We would like to thank lek. dent. Dariusz Mateńko \\ and prof. dr hab. Andrzej Wojtowizz for their \\ professional support and valuable comments.
}

Received on April 26, 2018

Reviewed on June 30, 2018

Accepted on 0ctober 17, 2018

Published online on December 4, 2018

Cite as

Nieckula P, Stempniewizz A, Tubaja M. Prophylaxis of osteonecrosis in the case of patients treated with bisphosphonates: A review paper. Dent Med Probl. 2018;55(4):425-429. doi:10.17219/dmp/99021

DOI

10.17219/dmp/99021

Copyright

○ 2018 by Wroclaw Medical University

and Polish Dental Society

This is an article distributed under the terms of the

Creative Commons Attribution Non-Commercial License

(http://creativecommons.org/licenses/by-nc-nd/4.0/)

\begin{abstract}
Bisphosphonates are a group of medicines used in the treatment of oncological osteoporosis, Paget disease and osteogenesis imperfecta. They significantly interfere with the regeneration processes of bone tissue and have a tendency to accumulate in the areas of increased bone remodeling, i.e., the maxilla and the mandible. One of their most serious and problematic side effects is the induction of bisphosphonaterelated osteonecrosis of the jaw (BRONJ), characterized by an exposed, necrotic bone in the maxillofacial area, which lasts longer than 8 weeks, in the case of a patient who is using or was using bisphosphonates and who did not undergo radiotherapy in this anatomical area. Dentistry manipulations are one of the factors which may increase the risk of BRONJ occurrence. The existing recommendations for preventing osteonecrosis are ambiguous. Some authors recommend that the bisphosphonate therapy be discontinued prior to dental procedures, while others say that there is no evidence for the effectiveness of interrupting the therapy. There is also no unequivocal attitude toward antibiotic prophylaxis. According to this research, each case should be considered individually, primarily having regard to the good of a patient.
\end{abstract}

Key words: oral health, bisphosphonates, prophylaxis, bone healing, osteonecrosis

Słowa kluczowe: zdrowie jamy ustnej, bisfosfoniany, profilaktyka, gojenie się kości, martwica kości 
Bisphosphonates are a group of medicines used in the treatment of malignancies metastatic to bone, multiple myeloma, hypercalcemia of malignancy, osteoporosis, Paget disease, and osteogenesis imperfecta. ${ }^{1,2}$

They belong to a group of inorganic pyrophosphatic derivatives and are a compound of 2 phosphonate groups connected by esterification. ${ }^{1}$ They can be divided into 2 groups: non-nitric and those containing 1 or more nitrogen atoms (Table 1). Their action is based on the affinity to bone hydroxyapatites, which inhibits bone disintegration and calcification. ${ }^{1,3}$ Moreover, bisphosphonates are able to induce the apoptosis of osteoclasts, which are responsible for bone destruction, as they release hydrolytic enzymes. The strong affinity of bisphosphonates to bone tissue and, in consequence, their accumulation in its structure, lead to their high concentration in the whole skeletal system. ${ }^{1}$ Those major properties have led to their medical utility.

Nowadays, apart from the obvious positive effects of using bisphosphonates, side effects such as gastrointestinal disorders, flu-like symptoms, nausea, emesis, headaches, dizziness, increased risk of atrial fibrillation, renal dysfunction, and the possibility of initiating the osteonecrosis of the jaw are also highlighted. ${ }^{1,4,5}$ The latter has recently been classified as a separate disease entity and described for the first time by Marx in 2003 on the basis of a study of 36 patients who took bisphosphonates intravenously. ${ }^{6}$ In fact, it is also diagnosed in the cases of drugs administered orally. It has been noticed that bisphosphonates significantly interfere with the regeneration processes of bone tissue. They have a tendency to accumulate in the areas of increased bone remodeling, i.e., the maxilla and the mandible. ${ }^{7}$

According to the American Association of Oral and Maxillofacial Surgeons (AAOMS), bisphosphonate-related osteonecrosis of the jaw (BRONJ) is an exposed, necrosis-affected bone in the maxillofacial area, which lasts longer than 8 weeks, in the case of a patient who is using or was using bisphosphonates and who did not undergo radiotherapy in this anatomical area. ${ }^{8}$ Teeth extractions, dental trauma, radio- and chemotherapy, infectious disease, and concomitant therapy with corticosteroids are listed as potential factors which may increase the risk of BRONJ development. ${ }^{9}$ Researchers highlight that BRONJ occurs mostly after an intravenous application of zoledronic acid. Among orally applied medicines, alendronate is the one that causes BRONJ most frequently. ${ }^{10}$
Clinical symptoms of BRONJ may vary - from an asymptomatic process to local pains, presence of fistulas, ulceration, inflammatory reaction of soft tissues, teeth loosening, and the exposure of a necrotic bone (Fig. 1).,11 Developing BRONJ may also cause sinus pain related to the thinning of the sinus walls and infection. ${ }^{12}$ A radiological picture shows the deterioration of the bone structure, bone defects that cannot be related to periodontitis, a loss of bone density, and the separating of bone sequestra (Fig. 2). ${ }^{13}$

In 2006, Ruggiero et al. developed a classification of BRONJ, which defines the advancement of necrosis. The $1^{\text {st }}$ stage includes patients with an exposed necrotic bone with no soft tissue inflammation. The $2^{\text {nd }}$ stage includes patients with an exposed necrotic bone with pain affliction and soft tissue infection. The $3^{\text {rd }}$ stage includes

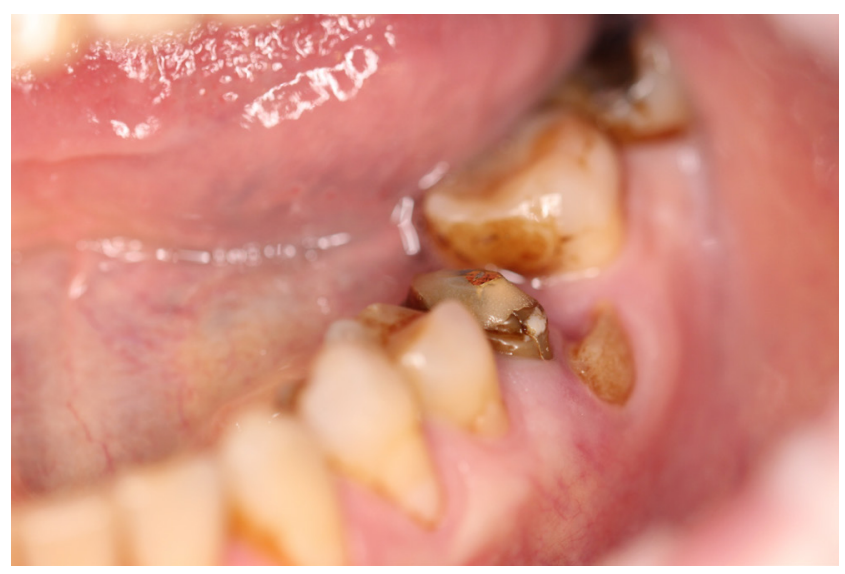

Fig. 1. Necrotic bone after the procedure of hemisection of distal root of first mandible molar - a patient using bisphosphonates

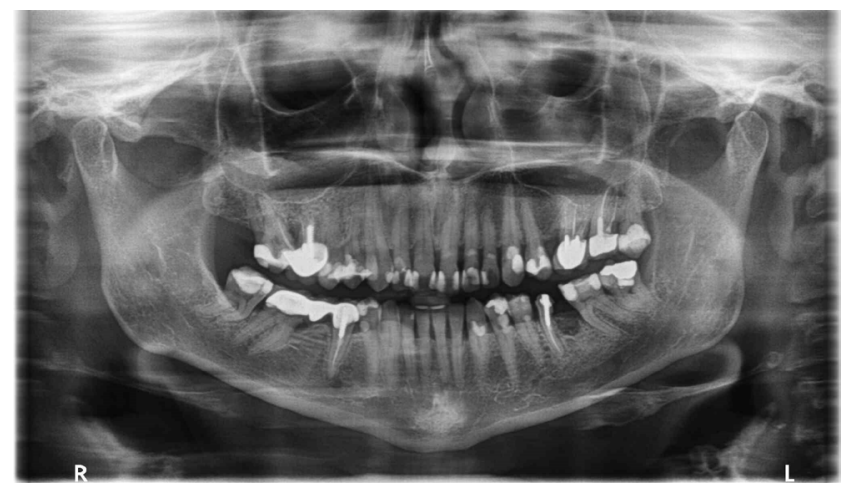

Fig. 2. Osteonecrosis after the procedure of hemisection of distal root of first mandible molar visible on orthopantomography of a patient using bisphosphonates

Table 1. Types of bisphosphonates

\begin{tabular}{|c|c|}
\hline Non-nitric bisphosphonates & Bisphosphonates with nitrogen atoms \\
\hline 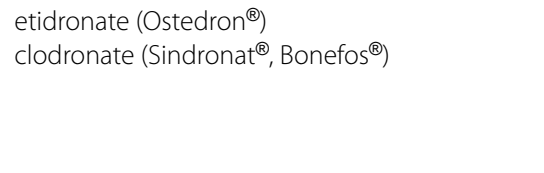 & $\begin{array}{l}\text { alendronate }\left(\text { Fosamax }{ }^{\circledR}, \text { Alendron }^{\circledR}\right)^{*} \\
\text { ibandronic acid }\left(\text { Bonviva }^{\circledR}, \text { Bondenza }^{\circledR} \text { ) }\right. \\
\text { zoledronate }\left(\text { Zometa }^{\circledR}, \text { Desinobon }^{\circledR}\right)^{*} \\
\text { pamidronate }\left(\text { Aredia }{ }^{\circledR}, \text { Pamifos }^{\circledR} \text { ) }\right. \\
\text { risedronate (Actonel }{ }^{\circledR}, \text { Risendros }^{\circledR} \text { ) }\end{array}$ \\
\hline
\end{tabular}

* bisphosphonates causing bisphosphonate-related osteonecrosis of the jaw (BRONJ) most frequently. 
patients who, in addition to the aforementioned symptoms, also present with pathological fractures, the creation of extraoral fistulas and osteolysis spreading to the edge of the mandible. ${ }^{9}$

In 2009, Bagán et al. noticed the need to update the previously developed classification of BRONJ, since it did not include a group of patients with intraoral fistulas without exposed necrotic bone tissue. They proposed a separate BRONJ classification. ${ }^{\text {acc.13 }}$ However, the most common classification was created by AAOMS; it differs from the abovementioned classifications (Table 2). ${ }^{8}$

Due to difficulties in treating the highlighted BRONJ complication of the bisphosphonate therapy, it seems to be reasonable to apply proper prophylaxis actions. The basis for preventing side effects is ensuring proper oral hygiene before commencing the bisphosphonate therapy. Teeth that do not qualify for conservative, endodontic or prosthetic treatment should be extracted. If possible, the treatment should be postponed until the extraction wound is fully healed. ${ }^{14}$

During the bisphosphonate treatment, the criteria for conservative and endodontic procedures do not differ from a standard case. Regular check-up visits every 4 months are very important during the therapy with bisphosphonates, and the treatment should be applied immediately in order to prevent the infection from spreading to bone tissue and to limit the need for possible surgical procedures. It is also recommended that patients be educated about maintaining perfect oral hygiene. Routine dental cleaning should be performed carefully to avoid the injuries of soft tissue. ${ }^{9}$

There is no proof of an increased risk of BRONJ after nonsurgical periodontics procedures. Using bisphosphonates does not change the criteria for prosthetic treatment; however, special attention should be paid to the correct moulding of dentures. They should not traumatize the tissues of denture foundation. ${ }^{15}$ Both intravenously and orally applied bisphosphonates are not contraindications to orthodontic treatment; however, they can slow down the moves of teeth during the treatment. ${ }^{16}$

Surgical procedures require separate prevention methods. The research shows that the inhibition of the bisphosphonate therapy before a surgical procedure does not decrease the risk of BRONJ. ${ }^{17}$ It has been proven that the concentration of bisphosphonates remains high for many years after the therapy. The exact duration of the half-life period of bisphosphonates is not well defined due to technical difficulties in marking their concentration in the urine and blood. It is estimated that alendronate can stay in the organism for 10 years, even after applying a single dose. ${ }^{1}$

If it is necessary to perform a surgical procedure in the maxillofacial area on a patient using bisphosphonates, the patient should always be informed about the potential risk of bone necrosis. It is also advised to perform the procedure in an atraumatic way by an experienced surgeon. It is also recommended to sew the wound tightly, without too much tension, and to maintain good oral hygiene, assisted with antibacterial solutions. ${ }^{18,19}$ The scientific research does not provide unambiguous conclusions with regard to applying the antibiotic therapy in BRONJ prevention.

Antibiotic prophylaxis is used in oral surgery to prevent infections in high-risk cases, i.e., in patients whose general health conditions or specific medical procedures they have undergone make them more susceptible to contracting new infections. There are many reasons to use antibiotic prophylaxis in patients treated with bisphosphonates because of their specific mechanism of action, connected with suppressed bone remodeling, inhibited angiogenesis, delayed healing, immunology dysfunction, and the toxification of soft tissues. ${ }^{20}$

Penicillin still remains a drug of choice in antibiotic prophylaxis, but the decision which medicine should be used depends on the pathogens, the patient's tolerance or allergies, and costs. The results of microbiological examinations taken from the extraction site at the time of procedure may be helpful in this regard. ${ }^{9}$

According to Hoefert and Eufinger, a longer application of antibiotics may have a positive influence on the healing process. They compared the results of 2 groups of patients. In the $1^{\text {st }}$ group, the antibiotic therapy was maintained for 1-8 days, while in the $2^{\text {nd }}$ one, it lasted for 23-54 days. The researchers noticed that in the $2^{\text {nd }}$ group, full healing was achieved in $70-87 \%$ of the cases, in contrast to the $1^{\text {st }}$ group with the results oscillating from $35 \%$ to $53 \%{ }^{21}$ The efficacy of this approach is confirmed by the research which analyzed the frequency of BRONJ occurrence after dental procedures. ${ }^{14}$ The occurrence of BRONJ was noted only in the group of patients who had not received the antibiotic therapy. Instead, the treatment used mostly amoxicillin or amoxicillin with clavulanate and metronidazole. The alternative for allergic patients is erythromycin, clindamycin and lincomycin. Suggested medicine doses are presented in Table $3 .^{20}$

Table 2. Classification of bisphosphonate-related osteonecrosis of the jaw (BRONJ) by the American Association of Oral and Maxillofacial Surgeons (AAOMS)

\begin{tabular}{|c|c|}
\hline Stage & Advancement of necrosis \\
\hline 0 & lack of a clinical proof of bone necrosis, still the presence of nonspecific clinical symptoms \\
\hline 1 & exposure of a necrotic bone without symptoms of infection \\
\hline 2 & exposure of a necrotic bone, accompanied by infection, pain, erythema with or without purulent exudate \\
\hline 3 & $\begin{array}{l}\text { exposure of a necrotic bone with pain, infection and } 1 \text { or more of the following: exposure of a necrotic bone causing pathological fractures, } \\
\text { extraoral fistula, oral-sinus fistula, or osteolysis spreading to the edge of the mandible or to the maxillary sinus }\end{array}$ \\
\hline
\end{tabular}


However, due to the extended period of administering antibiotics, the usage of clindamycin should be considered carefully, because of the high probability of side effects, including pseudomembranous colitis. Some studies show that clindamycin prophylaxis may also be insufficient for some Gram-negative bacteria, because of the bacteriostatic mechanism of action. ${ }^{22,23}$

On the other hand, there are authors who do not advise prescribing antibiotic prevention for routine dentistry, but recommend bacterial prophylaxis only for patients from the high-risk group with cardiovascular diseases. Some research does not confirm the effectiveness of antibiotic usage in preventing BRONJ. ${ }^{15,24}$

Observations of 15 patients in the Department of Dental Surgery at Medical University of Warsaw suggest that good results in preventing BRONJ were achieved by using antibiotics according to the following guidelines: antibiotic (amoxicillin $1 \mathrm{~g}$ every $12 \mathrm{~h}$ ) for 3 days before the procedure and on the day of the procedure, and then for \pm 21 days until the epithelialization of the wound. The wound was dressed with sutures, removed after 7-14 days, and the patient was examined on a weekly basis for wound regeneration. Moreover, the advanced platelet rich fibrin (A-PRF) fraction, obtained from the patient's blood collected before the procedure, can be used to accelerate post-extraction wound healing. The effectiveness of the antibiotic prophylaxis used in the Department of Dental Surgery at Medical University of Warsaw was proven in the study by Giovanni et al. ${ }^{\text {acc. } 9}$ In the group of patients who received antibiotics for 3 consecutive days before the procedure, on the day of the procedure and 17 days after, BRONJ was not noticed. ${ }^{9}$

It is difficult to define unambiguous rules of using prophylaxis in the cases of osteonecrosis of the jaws, being a result of the bisphosphonate therapy. Each case should be considered individually, having regard to the good of the patient. Doctors should remember that the chances to encounter people using bisphosphonates (both men and women) in the ageing Polish society are significant. These patients might not inform the dentist about using this medicine or may simply not be aware that this could affect the process of wound healing. It seems reasonable to pay more attention to a general medical interview, which would facilitate proper prophylaxis application.

\section{References}

1. Drake MT, Clarke BL, Khosla S. Bisphosphonates: Mechanism of action and role in clinical practice. Mayo Clin Proc. 2008;83:1032-1045.

2. American Dental Association Council on Scientific Affairs. Dental management of patients receiving oral bisphosphonate therapy: Expert panel recommendations. J Am Dent Assoc. 2006;137:1144-1150.

3. Migliorati CA, Siegel MA, Elting LS. Bisphosphonate-associated osteonecrosis: A long-term complication of bisphosphonate treatment. Lancet Oncol. 2006;7:508-514.

4. Varun B, Sivakumar T, Nair BJ, Joseph AP. Bisphosphonate induced osteonecrosis of jaw in breast cancer patients: A systematic review. J Oral Maxillofac Pathol. 2012;16:210-214.

5. Sarin J, DeRossi SS, Akintoye SO. Updates on bisphosphonates and potential pathobiology of bisphosphonate-induced jaw osteonecrosis. Oral Dis. 2008;14:277-285.

6. Marx RE. Pamidronate (Aredia) and zoledronate (Zometa) induced avascular necrosis of the jaws: A growing epidemic. J Oral Maxillofac Surg. 2003;61:1115-1117.

7. Leśniak W, Chloupek A, Biernacka B, et al. Bisphosphonate-associated osteonecrosis of the jaws. Case reports [in Polish]. Pediatr Med Rodz. 2013;9:197-200.

8. Ruggiero SL, Dodson TB, Assael LA, Landesberg R, Marx RE, Mehrotra B. American Association of Oral and Maxillofacial Surgeons Position Paper on bisphosphonate-related osteonecrosis of the jaw - 2009 update. Aust Endod J. 2009;35:119-130.

9. Ruggiero SL, Gralow J, Marx RE, et al. Practical guidelines for the prevention, diagnosis, and treatment of osteonecrosis of the jaw in patients with cancer. J Oncol Pract. 2006;2:7-14.

10. Pelaz A, Junquera L, Gallego L, et al. Epidemiology, pharmacology and clinical characterization of bisphosphonate-related osteonecrosis of the jaw. A retrospective study of 70 cases. Acta Otorrinolaringol Esp. 2015;66:139-147.

11. Kolur T, Nair SC, Kumar B. Osteonecrosis of maxilla secondary to bisphosphonate therapy: A case report. J Maxillofac Oral Surg. 2015;14:52-56.

12. Salvatore L, Ruggiero SL, Fantasia J, Carlson E. Bisphosphonates related osteonecrosis of the jaws. Oral Surg Oral Med Oral Pathol Oral Radiol Endod. 2006;102:433-441.

Table 3. Antibiotic therapy schemas

\begin{tabular}{|c|c|c|c|}
\hline \multicolumn{4}{|c|}{ Orally and intravenously applied bisphosponates } \\
\hline Study & Antibiotic used & Frequency of use & Time of use \\
\hline $\begin{array}{l}\text { Lodi et al. } \\
2004^{24}\end{array}$ & amoxicillin & 1 g every $8 \mathrm{~h}$ & 3 days before extraction, antibiotic therapy continued for 17 days \\
\hline \multirow{3}{*}{$\begin{array}{l}\text { Saia et al. } \\
2010^{25}\end{array}$} & amoxicillin with clavulanic acid & $\begin{array}{l}1 \mathrm{~g} \text { every } 8 \mathrm{~h} \text { for } 3 \text { days, then } \\
1 \mathrm{~g} \text { every } 12 \mathrm{~h} \text { for } 4 \text { days } \\
\text { (together with metronidazole) }\end{array}$ & \multirow{3}{*}{$\begin{array}{l}7 \text { days before extraction, in case of the occurrence of pain conditions, } \\
\text { antibiotic therapy continued for additional } 7 \text { days }\end{array}$} \\
\hline & metronidazole & $0.5 \mathrm{~g}$ every $8 \mathrm{~h}$ for 4 days & \\
\hline & in case of allergies: lincomycin & $0.5 \mathrm{~g}$ every $12 \mathrm{~h}$ & \\
\hline \multicolumn{4}{|c|}{ Intravenously applied bisphosponates } \\
\hline Study & Antibiotic used & Frequency of use & Time of use \\
\hline $\begin{array}{l}\text { Scoletta et al. } \\
2011^{26}\end{array}$ & $\begin{array}{l}\text { amoxicillin / potassium clavulanate } \\
\text { in case of allergies: erythromycin }\end{array}$ & $\begin{array}{l}1 \mathrm{~g} \text { every } 8 \mathrm{~h} \\
0.6 \mathrm{~g} \text { every } 8 \mathrm{~h}\end{array}$ & 1 day before extraction, antibiotic therapy continued for 5 following days \\
\hline $\begin{array}{l}\text { Ferlito et al. } \\
2011^{27}\end{array}$ & amoxicillin with clavulanic acid & $1 \mathrm{~g}$ every $12 \mathrm{~h}$ & 2 days before extraction, antibiotic therapy continued for 5 following days \\
\hline
\end{tabular}


13. Gavaldá C, Bagán JV. Concept, diagnosis and classification of bisphosphonate-associated osteonecrosis of the jaws. A review of the literature. Med Oral Patol Oral Cir Buccal. 2016;21:260-270.

14. Montefusco V, Gay F, Spina F, et al. Antibiotic prophylaxis before dental procedures may reduce the incidence of osteonecrosis of the jaw in patients with multiple myeloma treated with bisphosphonates. Leuk Lymphoma. 2008;49:2156-2162.

15. Edwards BJ, Hellstein JW, Jacobsen PL, Kaltman S, Mariotti A, Migliorati CA; American Dental Association Council on Scientific Affairs Expert Panel on Bisphosphonate-Associated Osteonecrosis of the Jaw. Updated recommendations for managing the care of patients receiving oral bisphosphonate therapy: An advisory statement from the American Dental Association Council on Scientific Affairs. J Am Dent Assoc. 2008;139:1674-1677.

16. Iglesias-Linares A, Yáñez-Vico RM, Solano-Reina E, Torres-Lagares $D$, González Moles MA. Influence of bisphosphonates in orthodontic therapy: Systematic review. J Dent. 2010;38:603-611.

17. European Medicines Agency. CHMP Assessment Report on Bisphosphonates and Osteonecrosis of the Jaw. London, 2009. https://www.ema. europa.eu/documents/report/chmp-assessment-report-bisphosphonates-osteonecrosis-jaw-procedure-under-article-53-regulationec-no/2004_en.pdf. Accessed March 20, 2018.

18. Frank S, Fiołna K, Wojtowicz A. Bisphosphonate-related osteonecrosis of the jaw. A review of the literature [in Polish]. Dental Forum. 2013;41:79-82.

19. Heufelder MJ, Hendricks J, Remmerbach T, Frerich B, Hemprich A, Wilde F. Principles of oral surgery for prevention of bisphosphonate-related osteonecrosis of the jaw. Oral Surg Oral Med Oral Pathol Oral Radiol. 2014;117:429-435.

20. Bermúdez-Bejarano EB, Serrera-Figallo MA, Gutiérrez-Corrales A, et al. Prophylaxis and antibiotic therapy in management protocols of patients treated with oral and intravenous bisphosphonates. J Clin Exp Dent. 2017;9:141-149.

21. Hoefert $\mathrm{S}$, Eufinger $\mathrm{H}$. Relevance of a prolonged preoperative antibiotic regime in the treatment of bisphosphonate-related osteonecrosis of the jaw. J Oral Maxillofac Surg. 2011;69:362-380.

22. Ching-Hsiang Y, Khong-Yik C, Solomkin J, Pao-Yuan L, Yuan-Cheng C, Yur-Ren K. Surgical site infections among high-risk patients in clean-contaminated head and neck reconstructive surgery: Concordance with preoperative oral flora. Ann Plas Surg. 2013;71:55-60.

23. Cannon RB, Houlton JJ, Mendez E, Futran ND. Methods to reduce postoperative surgical site infections after head and neck oncology surgery. Lancet Oncol. 2017;18:405-413.

24. Lodi G, Sardella A, Salis A, Demarosi F, Tarozzi M, Carrassi A. Tooth extraction in patients taking intravenous bisphosphonates: A preventive protocol and case series. J Oral Maxillofac Surg. 2010;68:107-110.

25. Saia G, Blandamura S, Bettini G, et al. Occurrence of bisphosphonate-related osteonecrosis of the jaw after surgical tooth extraction. J Oral Maxillofac Surg. 2010;68:797-804.

26. Scoletta M, Arduino PG, Pol R, et al. Initial experience on the outcome of teeth extractions in intravenous bisphosphonate-treated patients: A cautionary report. J Oral Maxillofac Surg. 2011;69:456-462.

27. Ferlito S, Puzzo S, Liardo C. Preventive protocol for tooth extractions in patients treated with zoledronate: A case series. J Oral Maxillofac Surg. 2011;69:e1-e4. 
